OPEN ACCESS

Edited by:

Vicente Herranz-Pérez,

University of Valencia, Spain

Reviewed by:

Jangho Kim,

Chonnam National University,

South Korea

Hans Joerg Meisel,

Berufsgenossenschaftliche Kliniken

Bergmannstrost Halle, Germany

*Correspondence:

Jun Fan

jfan@cmu.edu.cn

${ }^{\dagger}$ These authors have contributed equally to this work

Specialty section:

This article was submitted to

Stem Cell Research,

a section of the journal

Frontiers in Cell and Developmental

Biology

Received: 05 January 2021

Accepted: 28 May 2021

Published: 22 June 2021

Citation:

Zhong Y, Li X, Wang F, Wang S,

Wang X, Tian X, Bai S, Miao D and

Fan J (2021) Emerging Potential

of Exosomes on Adipogenic

Differentiation of Mesenchymal Stem

Cells. Front. Cell Dev. Biol. 9:649552.

doi: 10.3389/fcell.2021.649552

\section{Emerging Potential of Exosomes on Adipogenic Differentiation of Mesenchymal Stem Cells}

\author{
Yuxuan Zhong ${ }^{1+}$, Xiang $\mathrm{Li}^{2+}$, Fanglin Wang ${ }^{1}$, Shoushuai Wang ${ }^{1}$, Xiaohong Wang ${ }^{1}$, \\ Xiaohong Tian', Shuling Bai', Di Miao ${ }^{3}$ and Jun Fan ${ }^{1 *}$ \\ 1 Department of Tissue Engineering, School of Fundamental Science, China Medical University, Shenyang, China, \\ 2 Department of Cell Biology, Key Laboratory of Cell Biology, Ministry of Public Health, Key Laboratory of Medical Cell \\ Biology, Ministry of Education, China Medical University, Shenyang, China, ${ }^{3}$ China Medical University-The Queen's \\ University of Belfast Joint College-Combination, Shenyang, China
}

The mesenchymal stem cells have multidirectional differentiation potential and can differentiate into adipocytes, osteoblasts, cartilage tissue, muscle cells and so on. The adipogenic differentiation of mesenchymal stem cells is of great significance for the construction of tissue-engineered fat and the treatment of soft tissue defects. Exosomes are nanoscale vesicles secreted by cells and widely exist in body fluids. They are mainly involved in cell communication processes and transferring cargo contents to recipient cells. In addition, exosomes can also promote tissue and organ regeneration. Recent studies have shown that various exosomes can influence the adipogenic differentiation of stem cells. In this review, the effects of exosomes on stem cell differentiation, especially on adipogenic differentiation, will be discussed, and the mechanisms and conclusions will be drawn. The main purpose of studying the role of these exosomes is to understand more comprehensively the influencing factors existing in the process of stem cell differentiation into adipocytes and provide a new idea in adipose tissue engineering research.

Keywords: exosomes, mesenchymal stem cell, adipogenic differentiation, adipogenesis, regenerative medicine

\section{INTRODUCTION}

Exosomes are membrane vesicles released to the extracellular environment after fusion of multivesicular endosomes and plasma membranes, and all types of cells can produce exosomes under normal or pathological conditions. The study of exosomes lasted for nearly 40 years. Trams et al. (1981) found exfoliated vesicles from cultured normal cells and tumor cells with an average diameter of 500-1000 nm, and suggested that these vesicles with physiological functions be called "exosomes." Johnstone et al. (1987) named them "exosomes." Due to the shortage of technology and insufficient understanding of exosomes, most of the exosomes studied in early years came from mammalian erythrocytes (Bette-Bobillo and Vidal, 1995) or lymphocytes (Raposo et al., 1996). With the deepening understanding of the composition and mechanism of exosomes, various cell-derived exosomes have triggered relevant studies. In general, exosomes are widely used as a kind of nanocarrier to treat tumors by delivering nucleic acids or drugs (Lim et al., 1997; 
Wang D. et al., 2020). However, with the development of cosmetic and regenerative medicine, there are also studies showing that exosomes secreted by stem cells can promote tissue and organ regeneration. Therefore, more and more researchers are involved in the study of exosomes roles in tissue regeneration (Zhang et al., 2017).

Mesenchymal stem cells (MSCs) are pluripotent adult stem cells with the potential of multilineage differentiation. They can differentiate into adipose, bone, muscle, nerve, and endothelial tissue cells under specific induction conditions (Caplan, 1991). MSCs are rich sources and have strong proliferation ability, and immune regulatory function. Therefore, the application of MSCs in regenerative medicine research is endless.

Adipogenic differentiation is an important direction of MSCs differentiation which has attracted much attention in recent years. Adipogenic differentiation plays an important role in the regeneration of damaged organs and the repair of adipose tissue (Zhao et al., 2017; Morissette Martin et al., 2018; Suzuki et al., 2019). Studies demonstrate that microRNAs and glucocorticoids are related with adipogenic differentiation (Han et al., 2019; Lorente-Cebrian et al., 2019). In addition, recent studies indicate that exosomes also play a significant role in regulating the adipogenic differentiation of MSCs. Exosomes promote or inhibit adipose production by delivering genes or proteins associated with fat formation (Zhang et al., 2017; Zuo et al., 2019).

In this review, we discussed the effect of exosomes on the adipogenic differentiation of MSCs based on the existing research, combined with the function of exosomes and the mechanism of adipogenic differentiation of MSCs, and summarized the mechanism and pathway of the influence, providing a reference for the study of exosomes effect on adipogenic differentiation of MSCs.

\section{MECHANISMS OF ADIPOGENIC DIFFERENTIATION OF MESENCHYMAL STEM CELLS}

Adipogenesis is a complex process involving many transcription factors and regulatory genes (Moseti et al., 2016). During the process of adipogenic differentiation, the morphology and function of mesenchymal stem cells change to adipocytes and cannot differentiate into osteocytes, myocytes and other cells (Chen et al., 2016; Nic-Can et al., 2019). Adipogenesis is mainly divided into two stages: commitment and terminal differentiation. MSCs formed pre-adipocytes and then eventually differentiate into mature adipocytes (Ambele et al., 2020; Wang F. et al., 2020). Specific detailed differentiation steps can be referred to the summary of our laboratory (Wang F. et al., 2020).

\section{CHARACTERISTICS AND FUNCTIONS OF EXOSOMES}

Exosomes are widely present in body fluids. Exosomes are one type of extracellular vesicles (EVs), which are nanoscale vesicles with diameters between 30 and $150 \mathrm{~nm}$. The release process of exosomes was first discovered during the differentiation of reticulocytes, and then it was found that B lymphocytes and dendritic cells could also produce exosomes (Harding et al., 1983; Raposo et al., 1996; Liang et al., 2019). The release of exosomes requires three stages: the plasma membrane invaginates to form early endosomes, then forms multivesicular bodies (MVBs) under the action of endosomal sorting complex (ESCRT), and finally fuses MVB with the plasma membrane to release exosomes (Hessvik and Llorente, 2018). The contents of exosomes include proteins, lipids, RNA and DNA (Lin et al., 2015).

\section{Isolation and Characterization of Exosomes}

The separation of exosomes from body fluids and the medium is an essential step, for the size of exosomes is too small to isolate. It is a very challenging task. There are many methods to separate exosomes, and the most suitable method can be selected according to the experimental needs. Ultracentrifugation is the most widely used separation method. It is easy to operate, inexpensive and time-consuming. Size-based methods for separating exosomes include ultrafiltration (UF), polymer precipitation, and size-exclusion chromatography (SEC), which only depends on size or molecular weight. UF is often used for size-based isolation of exosomes, which is timesaving and produces high purity exosomes. To compensate for the UF's difficulty in removing contaminated proteins, it is often used in combination with the ultracentrifugation (Kim et al., 2020). In addition, some studies have shown that a combination of ultrafiltration and size exclusion chromatography can greatly increase exosome production (Oeyen et al., 2018; Shu et al., 2020). Immunoaffinity purification requires fewer samples, is rapid, easy, and compatible with conventional laboratory equipment (Nakai et al., 2016). In addition to these conventional methods, it is important to develop new techniques to provide high purity exosomes. Microfluidics-based isolation technology utilizes innovative sorting mechanisms such as acoustic, electrophoretic, and electromagnetic manipulations to significantly reduce sample quantity, time consumption, and experimental reagents (Dorayappan et al., 2019). These methods are summarized and compared as follows (Table $\mathbf{1}$ ).

Several methods are used for the detection of yield and purity of exosomes such as protein staining, Western blot, and proteomic techniques (Gheinani et al., 2018). In order to observe and evaluate the morphological structure and chemical characteristics of exosomes, different techniques have been used to characterize exosomes, such as dynamic light scattering (DLS) and nanoparticle tracking analysis (NTA) for characterizing their size, atomic force microscopy (AFM) and transmission electron microscopy (TEM) for observing the morphology and biomolecular components of exosomes (Figure 1), and flow cytometry for characterizing protein molecules on the surface of exosomes (Jung and Mun, 2018; Nolan and Duggan, 2018; Skliar and Chernyshev, 2019). Raman spectroscopy was used to characterize the chemical structure of exosomes (Carmicheal et al., 2019). Flow cytometry is the most commonly used method 
TABLE 1 | Comparison of isolation methods of exosomes.

\begin{tabular}{|c|c|c|c|c|}
\hline & Isolation principle & Advantages & Disadvantages & References \\
\hline Ultracentrifugation & $\begin{array}{l}\text { Separate particle composition } \\
\text { according to density, size, and shape }\end{array}$ & $\begin{array}{l}\text { It is suitable for large sample } \\
\text { volumes and yields large } \\
\text { amounts of exosomes. }\end{array}$ & $\begin{array}{l}\text { Not suitable for the small } \\
\text { volumes of clinical samples. } \\
\text { Labor intensive and low } \\
\text { portability. }\end{array}$ & $\begin{array}{l}\text { Lobb et al., 2015; Li et al., } \\
2018\end{array}$ \\
\hline Ultrafiltration (UF) & $\begin{array}{l}\text { Based solely on size differences } \\
\text { between exosomes and other } \\
\text { particulate components }\end{array}$ & $\begin{array}{l}\text { Short time consuming and high } \\
\text { purity, does not require } \\
\text { expensive equipment. }\end{array}$ & $\begin{array}{l}\text { Difficult to remove } \\
\text { contaminated proteins. }\end{array}$ & $\begin{array}{l}\text { Oeyen et al., 2018; Kim } \\
\text { et al., } 2020\end{array}$ \\
\hline $\begin{array}{l}\text { Size exclusion } \\
\text { method (SEC) }\end{array}$ & & $\begin{array}{l}\text { High purity and retaining } \\
\text { biological activity. }\end{array}$ & $\begin{array}{l}\text { Requires dedicated equipment. } \\
\text { Not suitable for the enrichment } \\
\text { of exosomes. }\end{array}$ & $\begin{array}{l}\text { Koh et al., 2018; } \\
\text { Monguio-Tortajada et al., } \\
2019\end{array}$ \\
\hline Precipitate & & $\begin{array}{l}\text { Suitable for large sample size, } \\
\text { easy to operate without special } \\
\text { equipment }\end{array}$ & $\begin{array}{l}\text { There is no specificity for } \\
\text { non-exosomal material and low } \\
\text { purity. }\end{array}$ & $\begin{array}{l}\text { Soares Martins et al., 2018; } \\
\text { Coughlan et al., } 2020\end{array}$ \\
\hline $\begin{array}{l}\text { Immunoaffinity } \\
\text { purification }\end{array}$ & $\begin{array}{l}\text { Exosomes are isolated using } \\
\text { interactions between proteins (antigens) } \\
\text { and their antibodies, and specific } \\
\text { interactions between receptors and } \\
\text { ligands. }\end{array}$ & $\begin{array}{l}\text { Rapid, easy, and have greater } \\
\text { separation efficiency and } \\
\text { increased sensitivity. }\end{array}$ & $\begin{array}{l}\text { High cost, low yields. Need for } \\
\text { exosome tags. }\end{array}$ & $\begin{array}{l}\text { Greening et al., 2015; } \\
\text { Zarovni et al., 2015; Nakai } \\
\text { et al., } 2016\end{array}$ \\
\hline $\begin{array}{l}\text { Microfluidic-based } \\
\text { isolation technology }\end{array}$ & $\begin{array}{l}\text { Common isolation determinants, such } \\
\text { as size, density, and immunoaffinity but } \\
\text { also innovative sorting mechanisms, } \\
\text { such as acetic are exploited }\end{array}$ & $\begin{array}{l}\text { Fast, low cost and easy } \\
\text { automation }\end{array}$ & $\begin{array}{l}\text { Requiring some expertise. It is } \\
\text { obstructed by standardization. }\end{array}$ & $\begin{array}{l}\text { Contreras-Naranjo et al., } \\
2017 \text {; Dorayappan et al., } \\
2019\end{array}$ \\
\hline
\end{tabular}

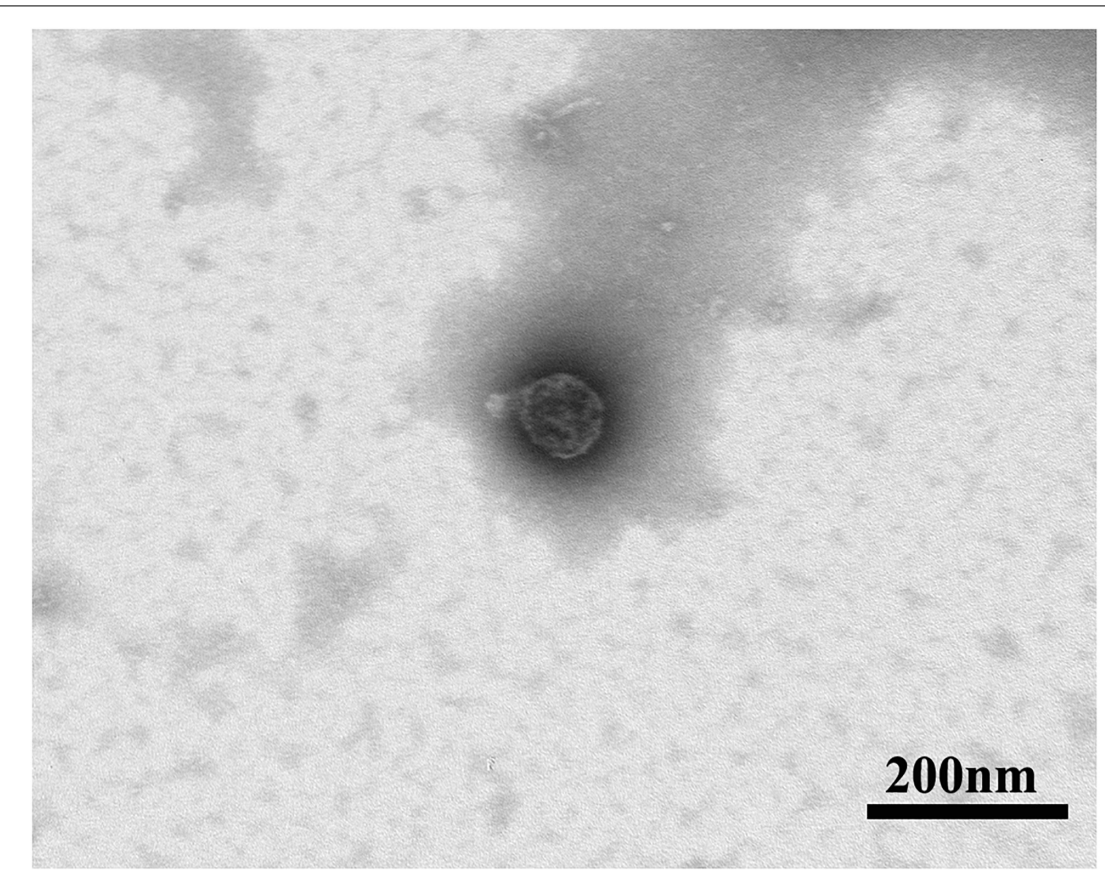

FIGURE 1 | Representative micrographs of transmission electron microscopy obtained from purified rat MSCs-derived exosomes (scale bar: 200 nm).

to analyze the biological characteristics of vesicles. These methods are summarized and compared as follows (Table 2).

\section{Function of Exosomes}

Exosomes are released from a variety of cells and exist widely in the body fluids of humans and other organisms. Their biological function and specificity depend on the type and state of the cells that release them. Because exosomes can transfer RNA, proteins, and lipids, they have many biological functions. Exosomes can affect cell proliferation, differentiation, apoptosis and migration. It was shown that MSC-derived exosomes promoted the growth of skin cells by increasing the phosphorylation of extracellular signal-regulated kinase (ERK)-1/2 (Kim et al., 2018). MSC exosome also promote proliferation and reduce apoptosis of adjacent cells in repairing cartilage loss (Zhang S. et al., 2018). In further, exosomes from cancer cells can induce cell migration 
TABLE 2 | Comparison of characterization methods of exosomes.

\begin{tabular}{|c|c|c|c|c|}
\hline & Purpose of characterization & Advantages & Disadvantages & References \\
\hline Western blot & $\begin{array}{l}\text { For the detection of yield and purity of } \\
\text { exosomes }\end{array}$ & $\begin{array}{l}\text { It is easy for use, and have the ability to } \\
\text { detect exosomal surface proteins and } \\
\text { internal proteins }\end{array}$ & $\begin{array}{l}\text { It's impossible to observe the intact } \\
\text { vesicles }\end{array}$ & $\begin{array}{l}\text { Szatanek et al., } \\
2017\end{array}$ \\
\hline DLS & $\begin{array}{l}\text { For estimating particle size and } \\
\text { concentration of exosomes }\end{array}$ & $\begin{array}{l}\text { It is able to measure particles ranging in } \\
\text { size from } 1 \mathrm{~nm} \text { to } 6 \mu \mathrm{m}\end{array}$ & $\begin{array}{l}\text { Analysis of heterogenous mixtures is } \\
\text { not easily performed }\end{array}$ & $\begin{array}{l}\text { Sokolova et al., } \\
2011\end{array}$ \\
\hline NTA & $\begin{array}{l}\text { For estimating particle size and } \\
\text { concentration of exosomes }\end{array}$ & very quick and easy using & $\begin{array}{l}\text { The original form could not be } \\
\text { determined }\end{array}$ & $\begin{array}{l}\text { Dragovic et al., } \\
2011\end{array}$ \\
\hline AFM/TEM & $\begin{array}{l}\text { For observing the morphology and } \\
\text { biomolecular components of exosomes }\end{array}$ & $\begin{array}{l}\text { The demand of sample preparation is } \\
\text { small and the operation is not } \\
\text { destructive }\end{array}$ & $\begin{array}{l}\text { Different samples require different } \\
\text { experimental conditions, such as } \\
\text { temperature, force between probe and } \\
\text { sample }\end{array}$ & $\begin{array}{l}\text { Yuana et al., 2010; } \\
\text { Wu et al., } 2015\end{array}$ \\
\hline Flow cytometry & $\begin{array}{l}\text { For characterizing exosomal surface } \\
\text { proteins and measuring the size and } \\
\text { structure of exosomes }\end{array}$ & $\begin{array}{l}\text { For analyzing the physical } \\
\text { characteristics and chemical } \\
\text { characteristics of exosomes }\end{array}$ & $\begin{array}{l}\text { It has limitations in terms of size, small } \\
\text { diameter particles cannot be detected }\end{array}$ & $\begin{array}{l}\text { Groot Kormelink } \\
\text { et al., } 2016\end{array}$ \\
\hline
\end{tabular}

of liver cancer cells (Chiba et al., 2016). There are also studies showing that exosomes also play a role in the immune response and inflammatory response Lv et al. (2018). For example, adipose tissue-derived stem cells (ADSCs)-derived exosomes promote macrophage polarization toward M2 phenotypes (Zhao et al., 2018). The exosomes produced by human embryonic stem cell derived MSCs can ameliorate interleukin-1beta (IL-1- $\beta$ )induced inflammatory effects (Zhang S. et al., 2019). In addition, exosomes also play an important role in angiogenesis. Exosomes released from chronic myelogenous leukemia cells regulate the process of neovascularization by activating the mitogen-activated protein kinase (MAPK) signaling pathway (Taverna et al., 2012). Exosomes from colorectal cancer cells contained miR$25-3 p$, which regulate vascular permeability and angiogenesis by suppressing the expression of Kruppel-like factor 2 (KLF2) and Kruppel-like factor 4 (KLF4) (Zeng et al., 2018). The sources and functions of several common exosomes are summarized as following (Table 3).

\section{THE EFFECT OF EXOSOMES ON THE DIFFERENTIATION OF MSCs}

The exosomes can specifically bind to target cells and regulate stem cell differentiation by increasing intercellular communication. Transcription factors, growth factors, and certain specific miRNAs and proteins contained in exosomes will affect differentiation of stem cells (Reilly and Engler, 2010; Whiteside, 2018; Chew et al., 2019). The exosomes can achieve stem cell lineage-specific differentiation. Narayanan et al. (2018) demonstrate that osteoblast-derived exosomes can accelerate osteogenic differentiation and increase the expression of osteogenic genes several times, but adipocyte-derived exosomes do not affect the expression of osteogenic genes. In a recent study, Zhu W. et al. (2020) found that exosomes extracted from non-traumatic osteonecrosis of the femoral head (ONFH) tissues inhibited osteogenic differentiation of murine MSCs due to lack of integrin CD41. In addition, exosomes secreted by human cholangiocarcinoma cells can induce fibroblastic differentiation in human bone marrow MSCs (h BM-MSCs) (Haga et al., 2015).

\section{Properties of Exosomes Derived From MSCs}

The exosomes secreted by MSCs first triggered research in 2010, which could reduce myocardial ischemia injury in mice, and then triggered many related studies, such as adipose stem cells secreted exosomes promoted angiogenesis (Lai et al., 2010; Zhang J. et al., 2018; Xu et al., 2019). There was no difference in morphology and isolation method between MSCs and other exosomes. MSCs secreted much more exosomes than other cells in terms of yield (Yeo et al., 2013). Besides, its surface markers include not only the CD9 and CD81 expressed by exosomes, but also some adhesion molecules, such as CD29, CD44, and CD73, expressed on the MSCs membrane (Lai et al., 2012). MSCs protein components in derived exosomes do not remain constant and aggregate according to the function of these proteins (Qiu et al., 2019). MiRNA in MSCs-derived exosomes mainly exist in their precursor form, and these miRNAs can participate in the biological activity of certain cells. The miR-143 contained in human MSCs secreted exosomes can be transferred to prostate cancer cells and inhibit prostate cancer by promoting its apoptosis. MiR-182 contained in mesenchymal stem cellderived exosomes can alter macrophage polarization (Che et al., 2019; Zhao et al., 2019).

\section{Ways of Exosomes Involvement in MSCs Differentiation}

\section{Endocytosis of Exosomes}

The exosomes can gain entry into target cells by way of fusion and/or endocytosis. The primary internalized mechanism is endocytosis, which includes macropinocytosis, clathrindependent endocytosis and clathrin-independent pathways (Gonda et al., 2019). MSCs can affect some specific protein and RNA levels in cell differentiation by endocytosis of exosomes (Svensson et al., 2013). It has been shown that fibroblasts can endocytose umbilical cord-derived exosomes and then inhibit myofibroblast formation by blocking the transforming growth factor- $\beta 2 /$ SMAD2 pathway (Fang et al., 2016). But the specific way of its endocytosis has not been explored. Macropinocytosis of exosomes is dependent on $\mathrm{Na}^{+}$and phosphatidylinositol 
TABLE 3 | The sources and functions of exosomes.

\begin{tabular}{|c|c|c|c|c|}
\hline Function & Sources & Related Genes and Proteins & Applications & References \\
\hline \multirow[t]{3}{*}{$\begin{array}{l}\text { Influence cell proliferation } \\
\text { and differentiation }\end{array}$} & Stem cell & $\operatorname{miR} 126$ & $\begin{array}{l}\text { Increasing the production of hematopoietic } \\
\text { stem cells (HSCs) for clinical use }\end{array}$ & Liao et al., 2018 \\
\hline & & $\begin{array}{l}\text { The PI3K/Akt signaling } \\
\text { pathway }\end{array}$ & Promote wound healing & $\begin{array}{l}\text { Zhang W. et al., } \\
2018\end{array}$ \\
\hline & & microRNA profiles & Treatment of bone tissue defects & Wang et al., 2018b \\
\hline \multirow[t]{2}{*}{$\begin{array}{l}\text { Destroy cell integrity and } \\
\text { inhibit cell apoptosis }\end{array}$} & $\begin{array}{l}\text { Human embryonic stem } \\
\text { cell-derived MSCs }\end{array}$ & - & Promote cartilage repair and regeneration & $\begin{array}{l}\text { Zhang S. et al., } \\
2018\end{array}$ \\
\hline & $\begin{array}{l}\text { Cardiac-resident progenitor } \\
\text { cells (CPCs) }\end{array}$ & $\begin{array}{l}\text { Pregnancy-associated plasma } \\
\text { protein-A (PAPP-A) }\end{array}$ & $\begin{array}{l}\text { Reduce cardiomyocyte apoptosis and protect } \\
\text { the heart }\end{array}$ & Barile et al., 2018 \\
\hline Mediates cell migration & Colorectal cancer cells & MAP & $\begin{array}{l}\text { It is helpful to explore the interaction between } \\
\text { cancer cells and adjacent normal cells in vivo }\end{array}$ & Chiba et al., 2016 \\
\hline \multirow[t]{2}{*}{ As a biomarker } & Colorectal cancer (CRC) cells & CK19 & As special markers for CRC & Xiao et al., 2019 \\
\hline & Placental Exosomes & $\begin{array}{l}\text { hsa-miR-486-1-5p, } \\
\text { hsa-miR-486-2-5p }\end{array}$ & Prevention of preeclampsia in pregnant women & $\begin{array}{l}\text { Salomon et al., } \\
2017\end{array}$ \\
\hline \multirow[t]{2}{*}{ Presentation of antigens } & Dendritic cells & & $\begin{array}{l}\text { Increased or decreased immune response with } \\
\text { medical treatment }\end{array}$ & $\begin{array}{l}\text { Shenoda and Ajit, } \\
\text { 2016; Lindenbergh } \\
\text { and Stoorvogel, } \\
2018\end{array}$ \\
\hline & $\begin{array}{l}\text { Human embryonic kidney } \\
\text { cells } 293 \text { (HEK293) }\end{array}$ & $\begin{array}{l}\text { Lactadherin }(\mathrm{LA}) \text {, } \\
\text { group-specific antigen (Gag) }\end{array}$ & $\begin{array}{l}\text { The loading of antigen proteins inside } \\
\text { exosomes helps in efficient antigen presentation }\end{array}$ & Arima et al., 2019 \\
\hline Mediate endocytosis & Macrophage & $\begin{array}{l}\text { GFP, T cell immunoglobulin } \\
\text { and mucin receptor } 1\end{array}$ & $\begin{array}{l}\text { Transfer of content by fusion of exosomes with } \\
\text { the plasma membrane, as an effective carrier of } \\
\text { antiviral therapy }\end{array}$ & Yao et al., 2018 \\
\hline Drug loading & $\begin{array}{l}\text { Bone marrow mesenchymal } \\
\text { stem cells (BM-MSC) }\end{array}$ & $\operatorname{miR}-125 b-5 p$ & $\begin{array}{l}\text { As a novel drug carrier that enhances the } \\
\text { specificity of drug delivery }\end{array}$ & Zhu et al., 2018 \\
\hline $\begin{array}{l}\text { Involvement in } \\
\text { inflammatory responses }\end{array}$ & Human embryonic stem cell & $\mathrm{IL}-1 \beta$ & Relief of temporomandibular joint osteoarthritis & $\begin{array}{l}\text { Zhang S. et al., } \\
2019\end{array}$ \\
\hline \multirow[t]{2}{*}{$\begin{array}{l}\text { Regulation of } \\
\text { angiogenesis }\end{array}$} & $\begin{array}{l}\text { Chronic myelogenous } \\
\text { leukemia }\end{array}$ & MAPK & $\begin{array}{l}\text { Exosomes induce endothelial cell ingrowth and } \\
\text { vascularization of Matrigel plugs in mice }\end{array}$ & Taverna et al., 2012 \\
\hline & Colorectal cancer cells & miR-25-3p & $\begin{array}{l}\text { Promotes vascular permeability and } \\
\text { angiogenesis }\end{array}$ & Zeng et al., 2018 \\
\hline
\end{tabular}

3-kinase (PI3K) (Tian et al., 2014). Exosomes size and cell type determine whether to use clathrin or caveolin. Commonly, exosomes smaller than $60 \mathrm{~nm}$ are absorbed by the endocytosis of caveolin, while clathrin-dependent mechanisms can internalize exosomes up to $120 \mathrm{~nm}$. Exosomes have tissue properties, such as hepatocytes rarely ingesting exosomes from non-hepatocytes (Yao et al., 2018). In general, exosomes can be used to affect stem cell differentiation by mediating endocytosis. The pathway of endocytosis depends on the cell type, the receptor on the cell surface, and the size of the exosomes.

\section{Exosomes Binding to Extracellular Matrix (ECM) Proteins}

Extracellular matrix (ECM) is a collagen-based structure containing a variety of proteins that can support cellular activities. ECM can serve as a bridge for cell communication and also influence cell differentiation fate (Rittie, 2015; Walker et al., 2018). Exosomes are invaginated vesicles in the plasma membrane, so the membrane of exosomes also belongs to the plasma membrane. Integrins and other receptors on the plasma membrane surface can bind to ECM proteins to promote MSCs differentiation (Clayton et al., 2004; Lin et al., 2019). It has been reported that exosomes can significantly up-regulate Runx2 and Osterix expression and promote MSCs osteogenic differentiation by binding to type I collagen hydrogel (Narayanan et al., 2016). Moreover, the combination of exosomes and tissue specific ECM switches on the lineage gene expressions at earlier time points of differentiation process compared to the exosomes or ECM conducted individually (Narayanan et al., 2018). Exosome binding to ECM can also promote organ function repair. For example, Zhang et al., found that combinatory transplantation of exosomes derived from gingival mesenchymal stem cells (GMSCs) and small intestinal submucosa-extracellular matrix (SIS-ECM) could promote the restoration of taste bud function (Zhang Y. et al., 2019). So, the exosomes may be used in combination of decellularized biological scaffolds to improve their performance.

\section{EXOSOMES REGULATE ADIPOGENIC DIFFERENTIATION}

The microenvironment of cell growth includes exosomes secreted by cells and various transforming factors, which are closely related to the differentiation of MSCs (Pittenger et al., 1999; Reilly and Engler, 2010). The proteins and miRNAs contained in exosomes play a decisive role in the various differentiation directions of MSCs (Narayanan et al., 2018). Exosomes 
contain osteogenesis-related miR-34a, miR-27a, and miR-22, adipogenesis-related miR-143 and miR-375 and other miRNAs (Shi et al., 2016; Narayanan et al., 2018). Therefore, based on the understanding of exosomes, many related studies on osteogenesis and adipogenesis have been initiated (Zhao et al., 2017; Zuo et al., 2019). Recent studies have found that some exosomes participate in adipogenic differentiation by being endocytosed by cells, and some exosomes can regulate adipogenesis by binding to ECM proteins. The mechanisms on exosomes affecting adipogenesis were summarized as follows (Table 4).

\section{Adipose Tissue}

\section{Exosomes $\rightarrow$ miR-450a-5p $\rightarrow$ WISP2}

A recent study demonstrates that exosomes secreted by rat adipose tissue contain abundant miRNAs that regulate cell differentiation. QPCR assays showed that the contents of miR450a-5p, miR-99a-5p, and miR-30a-5p were the most abundant (Zhang et al., 2017). In particular, miR-450a-5p plays an important role in adipogenesis. Among the targets of miR-450a$5 \mathrm{p}$, WNT1 inducible signaling pathway protein 2 (WISP2) was verified to be involved in adipogenesis (Hammarstedt et al., 2013). MiR-450a-5P can target the $3^{\prime}$ UTR of WISP2 to inhibit the expression of WISP2 (Bowers and Lane, 2007). Experiments showed that WISP2 was down-regulated with the up-regulation of miR-450a-5p during adipogenic culture of rat ADSCs. WISP2 is a classical WNT mediator that interacts with BMP4 to inhibit adipogenic differentiation in stereotyped 3T3-L1 pre-adipocytes (Xue et al., 2014). Inhibition of WISP2 by miR-450a-5p induces spontaneous adipogenic differentiation of stem cells.

Adipose tissue-derived stem cells promote adipogenesis only when ingesting adipose tissue-derived exosomes, but not when ingesting ADSCs-derived exosomes (Zhang et al., 2017). Other studies have found that exosomes from ADSCs transfer between macrophages rather than ADSCs (Zhao et al., 2018). Therefore, we can conclude that the transfer of exosomes is unidirectional, only unidirectional transfer from secreted cells to target cells. This suggests that the exosomes will not be absorbed by parental cells when they are used as carriers to deliver the contents to the target cells.

\section{M1 Macrophage Exosomes $\rightarrow$ PPAR-Gamma}

Macrophages are important participants in the immune response (Mosser and Edwards, 2008). Non-polarized (M0) macrophages can switch to polarized (M1 and M2) macrophages as needed when participating in various responses (Mantovani et al., 2013). Exosomes secreted by macrophages of all three phenotypes can be internalized by BM-MSCs and then participate in cell differentiation (Xia et al., 2020). Macrophages also play important roles in adipogenesis process. Early studies showed that M1 macrophages inhibited adipogenesis in PDGFR $\alpha^{+}$preadipocytes (Cheng et al., 2019). Recent studies have reported that exosomes secreted by M1 macrophages can significantly up-regulate the expression of PPAR-gamma gene to promote lipid droplet formation (Xia et al., 2020). However, exosomes secreted by M0 and M2 macrophages had negative effects on the lipid droplet formation of the BM-MSCs (Xia et al., 2020). In further, previous study demonstrated that the condition medium of M1 macrophage could promote the adipogenic differentiation of BM-MSCs. This suggested that exosomes may be involved in regulating the effect of macrophages-derived medium on the BM-MSCs' adipogenic differentiation.

According to the above studies, we conclude that the exosomes derived from macrophages can regulate adipogenesis process. This indicates that macrophages-derived exosomes may be as a candidate to promote the adipogenic differentiation of MSCs in the regenerative microenvironment.

\section{FBS Exosomes $\rightarrow \mathrm{miR}-1246$}

Fetal bovine serum (FBS) is the common additives in the cell culture medium. FBS contains high levels of growth factors which provides essential active ingredients for cell growth (Samareh Salavati Pour et al., 2020). Various kinds of regulatory RNAs including mRNA, miRNA, rRNA and so on were found in FBS (Wei et al., 2016). There is also a large number of $\mathrm{EV}$ in the FBS supplements, which contains miRNA, such as miR-122, miR-451a, and miR-1246 (Lehrich et al., 2018). Although high-speed centrifugation and other methods are used to remove PBS EV, some vesicles are still left, such as exosomes (Lehrich et al., 2018). FBS-derived exosomes exist in the microenvironment of cell growth, so its function cannot be ignored. A recent study demonstrated that FBS-derived exosomes could directly inhibit the adipogenic differentiation of the human bone marrow mesenchymal stromal cells (h BM-MSCs), and miR-1246 transferred by FBS exosomes may partly contribute to this effect. MiR-1246 has been shown to be rich in FBS secreted exosomes (Wei et al., 2016). MiR1246 can target early B cytokine 1 (EBF1) by binding to the site of EBF1 3'UTR. Experiments have identified EBF1 as a transcription factor expressed by adipocytes, which can promote fat decomposition (Gao et al., 2014).

TABLE 4 | Exosomes regulate adipogenic differentiation.

\begin{tabular}{|c|c|c|c|c|c|}
\hline Exosome source & RNA or Protein & Target genes or Signaling pathways & Target cells & Regulatory results & References \\
\hline Rat adipose tissue & $m i R-450 a-5 p$ & WISP2 & ADSCs & $\uparrow$ Adipogenesis & Zhang et al., 2017 \\
\hline M1 macrophage & - & PPAR-gamma & BM-MSCs & $\uparrow$ Adipogenesis & Xia et al., 2020 \\
\hline Fetal bovine serum (FBS) & miR-1246 & EBF1 & BM-MSCs & $\downarrow$ Adipogenesis & Zhou et al., 2020 \\
\hline Gastric cancer cell (GC) & ciRS-133 miR-133 & miR-133/PRDM16 & - & $\uparrow$ Adipogenesis & Zhang H. et al., 2019 \\
\hline Lung tumor A549 & - & TGF $\beta$ & ADMSCs & $\downarrow$ Adipogenesis & Wang et al., 2017 \\
\hline Tumor cell line K562 & miR-92a-3p & $\mathrm{C} / \mathrm{EBP} \alpha$ & Mouse ADSCs & $\downarrow$ Adipogenesis & Wan et al., 2019 \\
\hline
\end{tabular}


These results suggest that FBS exosomes are the negative regulator of adipogenic differentiation. When the medium of FBS additive is used in cell culture, the exosomes secreted by the FBS has a certain effect on the cell culture, and it should be included in the consideration of the influencing factors regulating lipogenesis.

\section{Gastric Cancer (GC) Exosomes $\rightarrow$ ciRS- $133 \rightarrow$ miR-133 $\rightarrow$ PRDM16}

At present, non-coding RNAs have been explored to be rich in exosomes. In addition to miRNA, a class of non-coding RNA, circular RNA, has also been found to be used to participate in the role of exosomes. Circular RNAs are produced by precursor mRNAs (pre-mRNAs) that have been shown to participate in lipid, osteogenic, and myogenic differentiation in cells (Wang Y. et al., 2019; Chen et al., 2020). Previous studies have shown that circ RNA is enriched and stable in exosomes (Li et al., 2015). A recent study found significant up-regulation of Hsa_circ_0010522 in GC exosomes, which was named ciRS133 because of its interaction with miR-133 that ciRS-133 is co-localized with miR-133. PR domain containing 16 (PRDM16), a zinc finger transcription factor, has been proposed to promote browning of white adipose tissue (WAT) (Van Nguyen et al., 2020). MiR-133 has been shown to be the upstream regulator of PRDM16, suppressing PRDM16 expression by targeting PRDM16 3'UTR in adipocytes. However, GC exosome-delivered ciRS-133 suppress the functionality of miR-133 to promote PRDM16 expression (Zhang H. et al., 2019). By inhibiting Mir133 to activate PRDM16, ciRS-133 activates uncoupling protein 1 (UCP1) and promotes pre-adiponectin browning (Yin et al., 2013; Zhang H. et al., 2019).

In addition, circular RNA can be used to modify ADSC exosomes to participate in cell differentiation (Zhu M. et al., 2020). This suggests that circular RNA could be an effective component of exosome lipid regulation.

\section{Lung Tumor Exosomes $\rightarrow$ TGF $\beta$}

Transforming growth factor $\beta$ (TGF $\beta$ ) signaling plays an important role in adipogenic and osteogenic differentiation. Transforming growth factor $\beta$ (TGF $\beta 1$ and TGF $\beta 2$ ) are both responsive genes in the TGF- $\beta$ pathway (Qian et al., 1987). TGF $\beta 1$ prevents adipogenic differentiation by inhibiting the expression of clade B (ovalbumin) member 2 (SERPINB2) which can promote cell osteogenic and adipogenic differentiation (Elsafadi et al., 2017). TGF $\beta 2$ inhibits C/EBP alpha and C/EBP $\beta$ to enhance serine phosphorylation of PPAR gamma, thereby inhibiting adipogenic differentiation of MSCs (Ahdjoudj et al., 2005). Early studies reported that tumor exosomes are closely related to tumor development, but recent studies have also shown that tumor exosomes also play a role in adipogenesis (Wang et al., 2016). As mentioned earlier, exosomes contain miRNAs that can regulate adipogenic differentiation, and studies have shown that adipose tissue mesenchymal stem cells (ADMSCs) can ingest lung tumor cell A549-derived exosomes, which inhibit adipogenic differentiation with decreased PPAR gamma expression. There are many pathways of adipogenesis, and the increase of phosphorylated Smad2 was reversed when the TGF $\beta$ inhibitor SB431542 was added (Wang et al., 2017). At the same time, the TGF $\beta$ pathway is activated, allowing the absorption of A549-derived exosomes to inhibit adipogenic differentiation (Ahdjoudj et al., 2005). The related miRNA and proteins of A549 cell line activation TGF $\beta$ pathway have not been revealed, so its specific mechanism needs further exploration.

The absorption of exosomes secreted by tumor cells usually triggers the inhibitory pathway of adipogenic differentiation. This results in more severe fat tissue defects in cancer patients, which prevent the formation of fat tissue. This means that cancer exosomes can be used as regulators of fat decomposition.

\section{Erythromyeloblastoid Leukemia Cell $\rightarrow$ miR-92a-3p $\rightarrow$ C/EBP $\alpha$}

In previous studies, miR-92a-3p has been found to enhance chondrogenesis by targeting WNT5A protein (Mao et al., 2018). There is a balanced relationship between osteogenesis and adipogenesis. Since miR-92a-3p is associated with osteogenesis, it may also be associated with adipogenesis. Studies reported that miR-92a-3p could regulate adipogenesis (Wan et al., 2019). MiRNA sequencing was performed in exosomes secreted by human erythromyeloblastoid leukemia cell and the characteristics of exosomes were analyzed. It was found that there were a large number of miR-92a-3p in both cells and exosomes (Wan et al., 2019). MiR-92a-3p is transferred into ADSCs by exosomes to participate in cell differentiation, and down-regulates $\mathrm{C} / \mathrm{EBP} \alpha$ and some lipogenic genes by directly targeting $\mathrm{C} / \mathrm{EBP} \alpha$. Low expression of $\mathrm{C} / \mathrm{EBP} \alpha$ can inhibit adipogenic differentiation of ADSCs (Zhang et al., 2004).

Tumor-associated exosomes uptake by adipocytes inhibited its lipogenesis. Mainly because it contains miRNA that reduces the expression of adipogenic gene $\mathrm{C} / \mathrm{EBP} \alpha, \operatorname{PPAR}-\gamma$ in adipocytes. This is also consistent with the loss of adipose tissue in cancer patients.

\section{POTENTIAL PATHWAYS OF EXOSOME REGULATION OF ADIPOGENESIS}

As shown above, exosomes contain abundant RNAs and proteins, which play a regulatory role in adipogenesis by being endocytosed by cells. In general, the components contained in exosomes are mainly involved in adipogenic differentiation by affecting the expression of C/EBP and PPAR or signaling pathways affecting adipogenesis. In addition to the aforementioned influence factors, there may be some potential targets.

\section{Human Umbilical Cord Mesenchymal Stem Cell-Derived Exosomes (HUMSC) $\rightarrow$ TGF $\beta$}

Human umbilical cord mesenchymal stem cell (HUMSC) has been continuously explored due to their non-invasive accessibility, low immunogenicity and high differentiation ability (Wang et al., 2004). Studies have shown that HUMSC can differentiate into adipocytes, chondrocytes, skeletal muscle and 
endothelial cells under certain induction conditions (Xing et al., 2016; Ji et al., 2020). HUMSC can differentiate into adipocytes, which suggest that the exosomes secreted by HUMSC may be involved in the adipogenic process. The experiment demonstrated that HUMSC secreted exosomes inhibited TGF $\beta 1$ signal (Hu et al., 2020). TGF $\beta 1$ is not only the key factor of fibroblast-myofibroblast transformation, but also the factor of inhibiting adipogenic differentiation. We speculate that HUMSC secreted exosomes may promote adipogenic differentiation by inhibiting TGF $\beta 1$ signal.

\section{BM-MSC $\rightarrow$ IGF-1}

BM-MSC improves renal insufficiency by local release of insulinlike growth factor 1 (IGF-1). In the exploration of exosomes secreted by human BM-MSC (hBM-MSC), IGF-1 receptor gene was found (Tomasoni et al., 2013). When these receptor genes are absorbed, the release of IGF-1 in BM-MSC can be promoted. Pre-adipocytes have a large number of IGF-1 receptors those bind to released IGF-1 to induce pre-adipocyte differentiation (Rabiee et al., 2018). The full-length pre-adipocyte factor (Pref1) inhibits pre-adipocyte differentiation, while IGF-1 can skip the blockade of Pref-1 (Zhang et al., 2003). The primary cilium is generated during the arrest phase of pre-adipocyte growth. The presence of primary cilia elevates the binding of IGF-1 to the receptor, prompting pre-adipocytes to continue to differentiate into adipocytes (Zhu et al., 2009). This suggests that BM-MSC may promote lipid differentiation by increasing the level of IGF-1.

\section{Neuronal Exosomes $\rightarrow$ Proline-Rich 7 (PRR7) $\rightarrow$ WNT}

Endogenous PRR7 has been demonstrated to exist in exosomes secreted by central neurons (Murata et al., 2005). Overexpression of PRR7 eliminates excitatory synapses in hippocampal nerves and decreases the amount of Wnt7a in exosomes. Removal of PRR7 increases the expression of Wnt5a and Wnt7a secreted from exosomes, which suggests that PRR7 has a role in inhibiting WNTS secretion (Lee et al., 2018). $\beta$-catenin is an important regulator of adipogenesis (Karczewska-Kupczewska et al., 2016). WNT binding to the receptor leads to inactivation of the $\beta$-catenin destruction complex (Komiya and Habas, 2008). The inactivation of the $\beta$-catenin destruction complex prevents the degradation of $\beta$-catenin. If $\beta$-catenin is not degraded, it can stably activate WNT target genes in the nucleus to activate WNT signaling pathway (Bowers and Lane, 2008). WNT signaling pathway can inhibit the terminal differentiation of pre-adipocytes to achieve the purpose of inhibiting adipogenesis (Davis and Zur Nieden, 2008; Bowers and Lane, 2008). Therefore, PRR7 may promote adipogenesis by inhibiting the WNT signaling pathway.

\section{APPLICATIONS OF EXOSOMES IN THE ADIPOSE TISSUE ENGINEERING}

Adipose tissue engineering can repair soft tissue defects and correct contour deformations, providing a solution for tissue reconstruction after soft tissue trauma. In recent years, ADSCs have been considered as ideal seed cells for adipose tissue engineering (Karagoz et al., 2019). However, many studies have shown that the reconstruction of adipose tissue produced by adipogenic differentiated MSCs is limited due to the shortage of oxygen and nutrients, so the formation of new blood vessels is very important in constructing adipose tissue engineering (Wang et al., 2018a). Exosomes play an important role in promoting angiogenesis. For example, injection of exosomes secreted by adipose stem cells to the skin flaps can improve flaps repair, protect the flaps, and induce the formation of new blood vessels (Karagoz et al., 2019). Due to exosomes have properties such as promoting cell proliferation and differentiation, and promoting angiogenesis, they have great potential to be used as a cellfree therapeutic approach in adipose tissue engineering (Dai et al., 2017). An engineered bioactive exosomal hydrogel (FHE hydrogel) has been invented to promote neovascularization and accelerate granulation tissue formation at the wound site (Wang C. et al., 2019). Several years ago, it was discovered that combining adipose derived stem cells with decellularized human adipose tissue extracellular matrix could be used for adipose tissue engineering (Wang et al., 2013). Recent studies have found that exosomes secreted by hADSCs can induce adipose tissue regeneration by combining with decellularized adipose tissues scaffold (Nie et al., 2020). In comparison, exosomes are less immunogenic and can be more conveniently injected into adipose tissue engineering scaffolds. Notably exosomes have better specialization in promoting adipogenic direction.

\section{DISCUSSION}

A lot of investigations show exosomes play an important role in determining the fate of stem cell differentiation. The functions of exosome participating in MSCs adipogenic differentiation mainly depends on the RNA and proteins it contains. Different origin of the exosomes may contain different types of contents and play different roles. For example, umbilical cord mesenchymal stem cell-derived exosomes are rich in miR-21, miR-23a, miR-125b, and miR-145, which can suppress myofibroblast differentiation (Fang et al., 2016). HMSC source exosome contains a large amount of miR-92a-3p that can promote chondrogenesis (Mao et al., 2018). miR-18a and miR-182 inclusion in ADSCs-derived exosomes can promote neurite outgrowth (Ching et al., 2018).

In the current researches on exosomes, exosomes mainly indirectly affect adipogenesis, and the regulation mode is simple. The exosomes involved in these studies are almost all influenced by endocytosis, which is dose-dependent, energy-dependent and protein-dependent. The effects of other functions, such as exosome and ECM protein binding, have been rarely studied. Researchers have demonstrated that exosomes can bind to fibronectin and type I collagen (Huang et al., 2016). The extracellular environment is closely related to the proliferation and differentiation of MSCs. The effect of exosomes binding to ECM proteins on cells is worth exploring in further study.

Exosomes play an important role in cellular communication. Due to its non-cellular properties, it is easy to transfer contents, such as mediating endocytosis and acting as a carrier. In the study of exosomes as drug carriers, many applications of delivering 


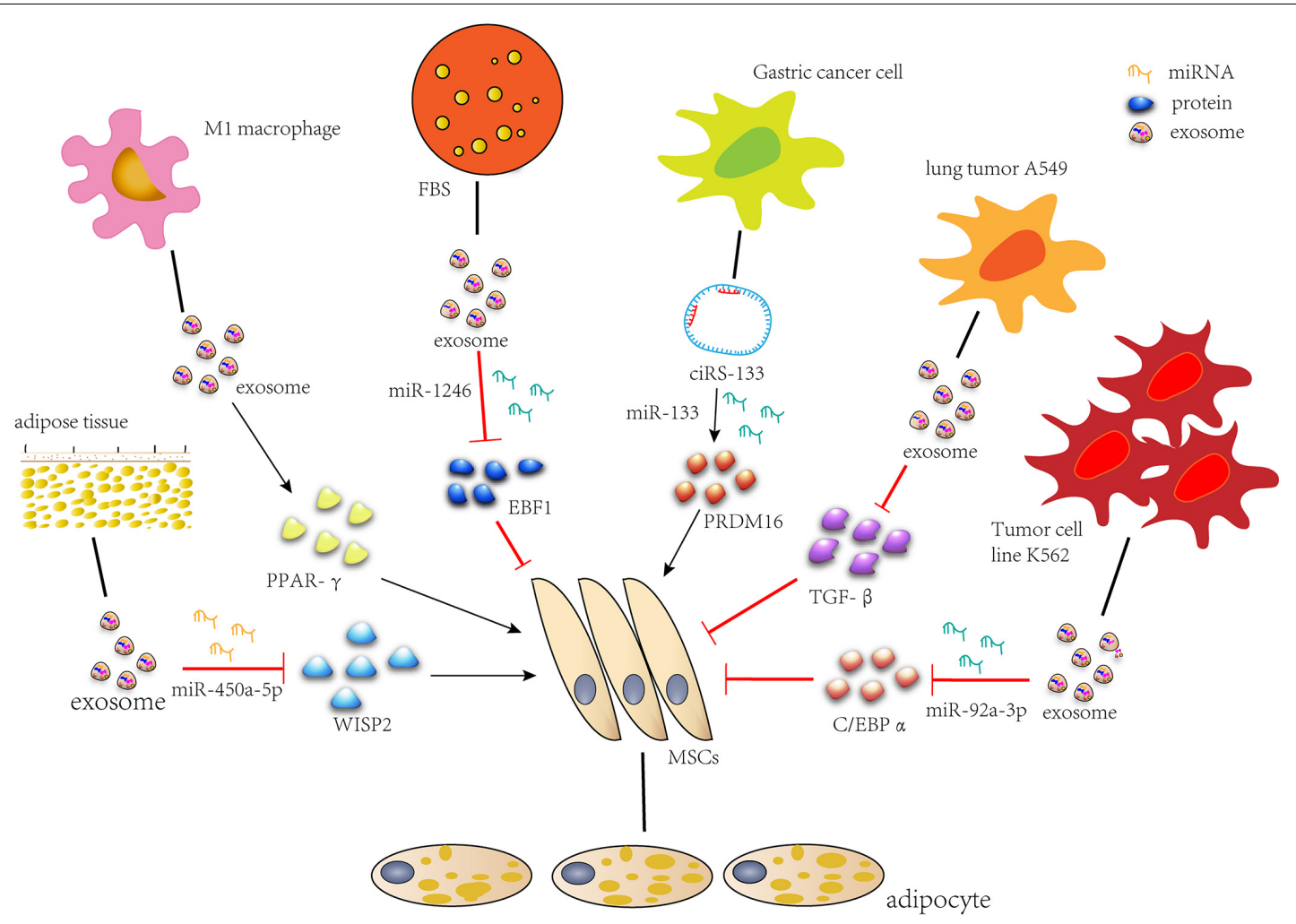

FIGURE 2 | Exosomes regulate adipogenic differentiation. miR-450a-5p contained in exosomes from rat adipose tissue promotes adipogenesis by inhibiting the expression of WISP2. Exosomes secreted by M1 macrophages significantly promote lipid droplet formation by up-regulating the expression of PPAR-gamma gene. miR-1246 in FBS secreted exosomes inhibits adipogenic differentiation by targeting EBF1. Gastric cancer exosome-delivered ciRS-133 promotes adipogenic differentiation by suppressing the functionality of miR-133 and promoting PRDM16 expression. Lung tumor cell A549-derived exosomes inhibit adipogenic differentiation via TGF $\beta$ signaling pathway. miR-92a-3p in K562 cell line inhibits adipogenesis of ADSC by reducing C/EBP $\alpha$ expression after transcription.

targeted drugs were applied to tumors treatment (Wang Y. et al., 2020). In subsequent studies to explore adipogenic differentiation, exosomes can be used as vectors to deliver miRNAs that we want to explore to target cells.

The mechanism of exosomes causing adipose tissue loss in the tumor direction has been intensive exploration. Tumor exosomes can inhibit lipogenesis by triggering signaling pathways, such as TGF and WNT, or inhibiting the expression of lipid-generating genes. Tumor exosomes should be regarded as an important factor in the decomposition of fat, which can be used as a candidate for preventing adipogenesis.

In order to improve the targeting ability, carrying capacity and specificity of exosomes, exosomes can be modified and processed by various improvement strategies. The EV modification could be achieved through direct modification of EVs or modification of the cells of origin used for EV production. Taking advantage of the porous nature of exosome membranes, physical methods such as electroporation and sonication can be used to load drugs and viruses directly to exosomes. Other chemical methods, such as Lipofection and drug incubation, can also directly improve exosome carrying capacity (Xu et al., 2020). Modification of EV originating cells that allows subsequent isolation of EVs, which already express the desired molecule. Tumor necrosis factor (TNF)-related apoptosis-inducing ligand (TRAIL) transduced leukemia cells can produce $\mathrm{TRAIL}^{+}$secreted exosomes (Rivoltini et al., 2016). This can modify the surface of exosomes, improve the receptor binding rate and enhance the targeting ability of exosomes. Further improvement of drug loading strategies and modification methods for engineered exosomes will be appreciated in future studies.

Exosomes not only affect adipogenesis by affecting the expression of lipid-generating genes C/EBP and PPAR, but also indirectly regulate adipogenesis by activating or inhibiting adipogenic signaling pathways. Due to the abundance of exosomes, the potential of exosomes to regulate MSCs differentiation is unlimited.

In adipose tissue regeneration, in addition to the adipogenesis, the lack of vascularization is another issue to overcome. Exosomes as a major form of intercellular communication, play essential roles in angiogenesis. Furthermore, recent studies demonstrate that several factors are involved in regulating the proangiogenic properties of exosomes (Anderson et al., 2016; Xue et al., 2018). The application of exosomes will enhance blood vessel formation which contribute to vascularized adipose tissue regeneration.

The current studies have shown that exosomes have great potential on adipogenic differentiation of mesenchymal stem cells, but the results are collected from the studies from cell and 
animal. There are no clinical trials on evaluating the exosomes on adipose formation in human. It is very important in clinics on exploring effectiveness and safety of exosomes.

\section{CONCLUSION}

During recent years, the role of exosomes in fat formation has been developed, and related studies have emerged. We summarized the previous work and formed the molecular network of the regulatory role of exosome in the lipid formation process of MSCs (Figure 2). We conclude that exosomes secreted by MSCs or stem cells associated with fat, as well as M1 macrophages and FBS, promote adipogenic differentiation, while exosomes secreted by tumors inhibit it. When adipogenesis is induced or tissue engineering adipose tissue is constructed, exosomes can be used to deliver RNAs, proteins and small drugs as a carrier. Tumor exosomes can be used when fat decomposes. In addition, an accurate setting of therapeutic doses of exosomes

\section{REFERENCES}

Ahdjoudj, S., Kaabeche, K., Holy, X., Fromigue, O., Modrowski, D., Zerath, E., et al. (2005). Transforming growth factor-beta inhibits CCAAT/enhancer-binding protein expression and PPARgamma activity in unloaded bone marrow stromal cells. Exp. Cell Res. 303, 138-147. doi: 10.1016/j.yexcr.2004.09.013

Ambele, M. A., Dhanraj, P., Giles, R., and Pepper, M. S. (2020). Adipogenesis: a complex interplay of multiple molecular determinants and pathways. Int. J. Mol. Sci. 21:4283. doi: 10.3390/ijms21124283

Anderson, J. D., Johansson, H. J., Graham, C. S., Vesterlund, M., Pham, M. T., Bramlett, C. S., et al. (2016). Comprehensive proteomic analysis of mesenchymal stem cell exosomes reveals modulation of angiogenesis via nuclear factor-KappaB signaling. Stem Cells 34, 601-613. doi: 10.1002/stem. 2298

Arima, Y., Liu, W., Takahashi, Y., Nishikawa, M., and Takakura, Y. (2019). Effects of localization of antigen proteins in antigen-loaded exosomes on efficiency of antigen presentation. Mol. Pharm. 16, 2309-2314. doi: 10.1021/ acs.molpharmaceut.8b01093

Barile, L., Cervio, E., Lionetti, V., Milano, G., Ciullo, A., Biemmi, V., et al. (2018). Cardioprotection by cardiac progenitor cell-secreted exosomes: role of pregnancy-associated plasma protein-A. Cardiovasc. Res. 114, 992-1005. doi: $10.1093 / \mathrm{cvr} / \mathrm{cvy} 055$

Bette-Bobillo, P., and Vidal, M. (1995). Characterization of phospholipase A2 activity in reticulocyte endocytic vesicles. Eur. J. Biochem. 228, 199-205. doi: 10.1111/j.1432-1033.1995.0199o.x

Bowers, R. R., and Lane, M. D. (2007). A role for bone morphogenetic protein4 in adipocyte development. Cell Cycle 6, 385-389. doi: 10.4161/cc.6.4. 3804

Bowers, R. R., and Lane, M. D. (2008). Wnt signaling and adipocyte lineage commitment. Cell Cycle 7, 1191-1196. doi: 10.4161/cc.7.9.5815

Caplan, A. I. (1991). Mesenchymal stem cells. J. Orthop. Res. 9, 641-650.

Carmicheal, J., Hayashi, C., Huang, X., Liu, L., Lu, Y., Krasnoslobodtsev, A., et al. (2019). Label-free characterization of exosome via surface enhanced Raman spectroscopy for the early detection of pancreatic cancer. Nanomedicine 16, 88-96.

Che, Y., Shi, X., Shi, Y., Jiang, X., Ai, Q., Shi, Y., et al. (2019). Exosomes derived from miR-143-overexpressing MSCs inhibit cell migration and invasion in human prostate cancer by downregulating TFF3. Mol. Ther. Nucleic Acids 18, 232-244. doi: 10.1016/j.omtn.2019.08.010

Chen, G., Wang, Q., Li, Z., Yang, Q., Liu, Y., Du, Z., et al. (2020). Circular RNA CDRlas promotes adipogenic and suppresses osteogenic differentiation of BMSCs in steroid-induced osteonecrosis of the femoral head. Bone 133:115258. doi: $10.1016 /$ j.bone.2020.115258 should also be considered. The utilization of exosomes to treat adipose tissue defect has a great potential clinical significance.

\section{AUTHOR CONTRIBUTIONS}

YZ, XL, FW, and JF: writing and editing. JF: conceptualization. SW: visualization of exosome by TEM. XW, XT, and SB: detailed techniques contribution. DM collected some literature. All authors contributed to the article and approved the submitted version.

\section{FUNDING}

This work was supported by the National Natural Science Foundation of China (no. 81571919) and LiaoNing Revitalization Talents Program (no. XLYC1907124).

Chen, Q., Shou, P., Zheng, C., Jiang, M., Cao, G., Yang, Q., et al. (2016). Fate decision of mesenchymal stem cells: adipocytes or osteoblasts? Cell Death Differ. 23, 1128-1139. doi: 10.1038/cdd.2015.168

Cheng, H., Luan, J., Mu, D., Wang, Q., Qi, J., Li, Z., et al. (2019). M1/M2 macrophages play different roles in adipogenic differentiation of PDGFRalpha (+) preadipocytes in vitro. Aesthetic Plast. Surg. 43, 514-520.

Chew, J. R. J., Chuah, S. J., Teo, K. Y. W., Zhang, S., Lai, R. C., Fu, J. H., et al. (2019). Mesenchymal stem cell exosomes enhance periodontal ligament cell functions and promote periodontal regeneration. Acta Biomater. 89, 252-264. doi: 10.1016/j.actbio.2019.03.021

Chiba, M., Watanabe, N., Watanabe, M., Sakamoto, M., Sato, A., Fujisaki, M., et al. (2016). Exosomes derived from SW480 colorectal cancer cells promote cell migration in HepG2 hepatocellular cancer cells via the mitogen-activated protein kinase pathway. Int. J. Oncol. 48, 305-312. doi: 10.3892/ijo.2015.3255

Ching, R. C., Wiberg, M., and Kingham, P. J. (2018). Schwann cell-like differentiated adipose stem cells promote neurite outgrowth via secreted exosomes and RNA transfer. Stem Cell Res. Ther. 9:266.

Clayton, A., Turkes, A., Dewitt, S., Steadman, R., Mason, M. D., and Hallett, M. B. (2004). Adhesion and signaling by B cell-derived exosomes: the role of integrins. FASEB J. 18, 977-979. doi: 10.1096/fj.03-1094fje

Contreras-Naranjo, J. C., Wu, H. J., and Ugaz, V. M. (2017). Microfluidics for exosome isolation and analysis: enabling liquid biopsy for personalized medicine. Lab. Chip 17, 3558-3577. doi: 10.1039/c7lc00592j

Coughlan, C., Bruce, K. D., Burgy, O., Boyd, T. D., Michel, C. R., Garcia-Perez, J. E., et al. (2020). Exosome isolation by ultracentrifugation and precipitation and techniques for downstream analyses. Curr. Protoc. Cell Biol. 88:e110.

Dai, M., Yu, M., Zhang, Y., and Tian, W. (2017). Exosome-like vesicles derived from adipose tissue provide biochemical cues for adipose tissue regeneration. Tissue Eng. Part A 23, 1221-1230. doi: 10.1089/ten.tea.2017.0045

Davis, L. A., and Zur Nieden, N. I. (2008). Mesodermal fate decisions of a stem cell: the Wnt switch. Cell Mol. Life Sci. 65, 2658-2674. doi: 10.1007/s00018-0088042-1

Dorayappan, K. D. P., Gardner, M. L., Hisey, C. L., Zingarelli, R. A., Smith, B. Q., Lightfoot, M. D. S., et al. (2019). A microfluidic chip enables isolation of exosomes and establishment of their protein profiles and associated signaling pathways in ovarian cancer. Cancer Res. 79, 3503-3513. doi: 10.1158/00085472.can-18-3538

Dragovic, R. A., Gardiner, C., Brooks, A. S., Tannetta, D. S., Ferguson, D. J., Hole, P., et al. (2011). Sizing and phenotyping of cellular vesicles using nanoparticle tracking analysis. Nanomedicine 7, 780-788. doi: 10.1016/j.nano.2011.04.003

Elsafadi, M., Manikandan, M., Atteya, M., Abu Dawud, R., Almalki, S., Ali Kaimkhani, Z., et al. (2017). SERPINB2 is a novel TGFbeta-responsive lineage fate determinant of human bone marrow stromal cells. Sci. Rep. 7:10797. 
Fang, S., Xu, C., Zhang, Y., Xue, C., Yang, C., Bi, H., et al. (2016). Umbilical cord-derived mesenchymal stem cell-derived exosomal micrornas suppress myofibroblast differentiation by inhibiting the transforming growth factorbeta/SMAD2 pathway during wound healing. Stem Cells Transl. Med. 5, 1425-1439. doi: 10.5966/sctm.2015-0367

Gao, H., Mejhert, N., Fretz, J. A., Arner, E., Lorente-Cebrian, S., Ehrlund, A., et al. (2014). Early B cell factor 1 regulates adipocyte morphology and lipolysis in white adipose tissue. Cell Metab. 19, 981-992. doi: 10.1016/j.cmet.2014.03.032

Gheinani, A. H., Vogeli, M., Baumgartner, U., Vassella, E., Draeger, A., Burkhard, F. C., et al. (2018). Improved isolation strategies to increase the yield and purity of human urinary exosomes for biomarker discovery. Sci. Rep. 8:3945.

Gonda, A., Kabagwira, J., Senthil, G. N., and Wall, N. R. (2019). Internalization of exosomes through receptor-mediated endocytosis. Mol. Cancer Res. 17, 337-347. doi: 10.1158/1541-7786.mcr-18-0891

Greening, D. W., Xu, R., Ji, H., Tauro, B. J., and Simpson, R. J. (2015). A protocol for exosome isolation and characterization: evaluation of ultracentrifugation, density-gradient separation, and immunoaffinity capture methods. Methods Mol. Biol. 1295, 179-209. doi: 10.1007/978-1-4939-2550-6_15

Groot Kormelink, T., Arkesteijn, G. J., Nauwelaers, F. A., van den Engh, G., Nolte-t Hoen, E. N., and Wauben, M. H. (2016). Prerequisites for the analysis and sorting of extracellular vesicle subpopulations by high-resolution flow cytometry. Cytometry A 89, 135-147. doi: 10.1002/cyto.a.22644

Haga, H. I, Yan, K., Takahashi, K., Wood, J., Zubair, A., and Patel, T. (2015). Tumour cell-derived extracellular vesicles interact with mesenchymal stem cells to modulate the microenvironment and enhance cholangiocarcinoma growth. J. Extracell. Vesicles 4:24900. doi: 10.3402/jev.v4.24900

Hammarstedt, A., Hedjazifar, S., Jenndahl, L., Gogg, S., Grunberg, J., Gustafson, B., et al. (2013). WISP2 regulates preadipocyte commitment and PPARgamma activation by BMP4. Proc. Natl. Acad. Sci. U.S.A. 110, 2563-2568. doi: 10.1073/ pnas. 1211255110

Han, L., Wang, B., Wang, R., Gong, S., Chen, G., and Xu, W. (2019). The shift in the balance between osteoblastogenesis and adipogenesis of mesenchymal stem cells mediated by glucocorticoid receptor. Stem Cell Res. Ther. 10:377.

Harding, C., Heuser, J., and Stahl, P. (1983). Receptor-mediated endocytosis of transferrin and recycling of the transferrin receptor in rat reticulocytes. J. Cell Biol. 97, 329-339. doi: 10.1083/jcb.97.2.329

Hessvik, N. P., and Llorente, A. (2018). Current knowledge on exosome biogenesis and release. Cell Mol. Life Sci. 75, 193-208. doi: 10.1007/s00018-0172595-9

Hu, J., Chen, Y., Huang, Y., and Su, Y. (2020). Human umbilical cord mesenchymal stem cell-derived exosomes suppress dermal fibroblastsmyofibroblats transition via inhibiting the TGF-betal/Smad 2/3 signaling pathway. Exp. Mol. Pathol. 115:104468. doi: 10.1016/j.yexmp.2020.104468

Huang, C. C., Narayanan, R., Alapati, S., and Ravindran, S. (2016). Exosomes as biomimetic tools for stem cell differentiation: applications in dental pulp tissue regeneration. Biomaterials 111, 103-115. doi: 10.1016/j.biomaterials.2016.09. 029

Ji, W., Chen, Y., Wang, L., Xu, Z., Ahmed, J., Ge, R., et al. (2020). Differentiation of human umbilical cord mesenchymal stem cells into Leydig-like cells with defined molecular compounds. Hum. Cell 33, 318-329. doi: 10.1007/s13577020-00324-y

Johnstone, R. M., Adam, M., Hammond, J. R., Orr, L., and Turbide, C. (1987). Vesicle formation during reticulocyte maturation. Association of plasma membrane activities with released vesicles (exosomes). J. Biol. Chem. 262, 9412-9420. doi: 10.1016/s0021-9258(18)48095-7

Jung, M. K., and Mun, J. Y. (2018). Sample preparation and imaging of exosomes by transmission electron microscopy. J. Vis. Exp. 131:56482.

Karagoz, H., Zor, F., Goktas, E., and Gorantla, V. S. (2019). Adipogenesis for soft tissue reconstruction. Curr. Opin. Organ. Transplant. 24, 598-603. doi: 10.1097/mot.0000000000000694

Karczewska-Kupczewska, M., Stefanowicz, M., Matulewicz, N., Nikolajuk, A., and Straczkowski, M. (2016). Wnt signaling genes in adipose tissue and skeletal muscle of humans with different degrees of insulin sensitivity. J. Clin. Endocrinol. Metab. 101, 3079-3087. doi: 10.1210/jc.2016-1594

Kim, S., Lee, S. K., Kim, H., and Kim, T. M. (2018). Exosomes secreted from induced pluripotent stem cell-derived mesenchymal stem cells accelerate skin cell proliferation. Int. J. Mol. Sci. 19:3119. doi: 10.3390/ijms19103119
Kim, Y. B., Yang, J. S., Lee, G. B., and Moon, M. H. (2020). Evaluation of exosome separation from human serum by frit-inlet asymmetrical flow fieldflow fractionation and multiangle light scattering. Anal. Chim. Acta 1124, 137-145. doi: 10.1016/j.aca.2020.05.031

Koh, Y. Q., Almughlliq, F. B., Vaswani, K., Peiris, H. N., and Mitchell, M. D. (2018). Exosome enrichment by ultracentrifugation and size exclusion chromatography. Front. Biosci. 23, 865-874. doi: 10.2741/4621

Komiya, Y., and Habas, R. (2008). Wnt signal transduction pathways. Organogenesis 4, 68-75. doi: 10.4161/org.4.2.5851

Lai, R. C., Arslan, F., Lee, M. M., Sze, N. S., Choo, A., Chen, T. S., et al. (2010). Exosome secreted by MSC reduces myocardial ischemia/reperfusion injury. Stem Cell Res. 4, 214-222. doi: 10.1016/j.scr.2009.12.003

Lai, R. C., Tan, S. S., Teh, B. J., Sze, S. K., Arslan, F., de Kleijn, D. P., et al. (2012). Proteolytic potential of the MSC exosome proteome: implications for an exosome-mediated delivery of therapeutic proteasome. Int. J. Proteomics 2012:971907.

Lee, S. H., Shin, S. M., Zhong, P., Kim, H. T., Kim, D. I., Kim, J. M., et al. (2018). Reciprocal control of excitatory synapse numbers by Wnt and Wnt inhibitor PRR7 secreted on exosomes. Nat. Commun. 9:3434.

Lehrich, B. M., Liang, Y., Khosravi, P., Federoff, H. J., and Fiandaca, M. S. (2018). Fetal bovine serum-derived extracellular vesicles persist within vesicle-depleted culture media. Int. J. Mol. Sci. 19:3538. doi: 10.3390/ijms19113538

Li, K., Wong, D. K., Hong, K. Y., and Raffai, R. L. (2018). Cushioned-Density Gradient Ultracentrifugation (C-DGUC): a refined and high performance method for the isolation, characterization, and use of exosomes. Methods Mol. Biol. 1740, 69-83. doi: 10.1007/978-1-4939-7652-2_7

Li, Y., Zheng, Q., Bao, C., Li, S., Guo, W., Zhao, J., et al. (2015). Circular RNA is enriched and stable in exosomes: a promising biomarker for cancer diagnosis. Cell Res. 25, 981-984. doi: 10.1038/cr.2015.82

Liang, Y. R., Zhang, T., Jia, P., Xu, X. L., Fang, Y., and Ding, X. Q. (2019). Interaction between bone marrow-derived dendritic cells and miR-21 of tubular renal epithelial cells under hypoxia. Eur. Rev. Med. Pharmacol. Sci. 23, 16411651.

Liao, F. L., Tan, L., Liu, H., Wang, J. J., Ma, X. T., Zhao, B., et al. (2018). Hematopoietic stem cell-derived exosomes promote hematopoietic differentiation of mouse embryonic stem cells in vitro via inhibiting the miR126/Notch1 pathway. Acta Pharmacol. Sin. 39, 552-560. doi: 10.1038/aps. 2017.130

Lim, J., Kuroki, T., Ozaki, K., Kohsaki, H., Yamori, T., Tsuruo, T., et al. (1997). Isolation of murine and human homologues of the fission-yeast dis $3+$ gene encoding a mitotic-control protein and its overexpression in cancer cells with progressive phenotype. Cancer Res. 57, 921-925.

Lin, F., Zeng, Z., Song, Y., Li, L., Wu, Z., Zhang, X., et al. (2019). YBX-1 mediated sorting of miR-133 into hypoxia/reoxygenation-induced EPC-derived exosomes to increase fibroblast angiogenesis and MEndoT. Stem Cell Res. Ther. 10:263.

Lin, J., Li, J., Huang, B., Liu, J., Chen, X., Chen, X. M., et al. (2015). Exosomes: novel biomarkers for clinical diagnosis. ScientificWorldJournal 2015:657086.

Lindenbergh, M. F. S., and Stoorvogel, W. (2018). Antigen presentation by extracellular vesicles from professional antigen-presenting cells. Annu. Rev. Immunol. 36, 435-459. doi: 10.1146/annurev-immunol-041015-055700

Lobb, R. J., Becker, M., Wen, S. W., Wong, C. S., Wiegmans, A. P., Leimgruber, A., et al. (2015). Optimized exosome isolation protocol for cell culture supernatant and human plasma. J. Extracell. Vesicles 4:27031. doi: 10.3402/jev.v4.27031

Lorente-Cebrian, S., Gonzalez-Muniesa, P., Milagro, F. I., and Martinez, J. A. (2019). MicroRNAs and other non-coding RNAs in adipose tissue and obesity: emerging roles as biomarkers and therapeutic targets. Clin. Sci. 133, 23-40. doi: $10.1042 / \operatorname{cs} 20180890$

Lv, L. L., Feng, Y., Wen, Y., Wu, W. J., Ni, H. F., Li, Z. L., et al. (2018). Exosomal CCL2 from tubular epithelial cells is critical for albumin-induced tubulointerstitial inflammation. J. Am. Soc. Nephrol. 29, 919-935. doi: 10.1681/ asn. 2017050523

Mantovani, A., Biswas, S. K., Galdiero, M. R., Sica, A., and Locati, M. (2013). Macrophage plasticity and polarization in tissue repair and remodelling. J. Pathol. 229, 176-185. doi: 10.1002/path.4133

Mao, G., Zhang, Z., Hu, S., Zhang, Z., Chang, Z., Huang, Z., et al. (2018). Exosomes derived from miR-92a-3p-overexpressing human mesenchymal stem 
cells enhance chondrogenesis and suppress cartilage degradation via targeting WNT5A. Stem Cell Res. Ther. 9:247.

Monguio-Tortajada, M., Galvez-Monton, C., Bayes-Genis, A., Roura, S., and Borras, F. E. (2019). Extracellular vesicle isolation methods: rising impact of size-exclusion chromatography. Cell Mol. Life Sci. 76, 2369-2382. doi: 10.1007/ s00018-019-03071-y

Morissette Martin, P., Shridhar, A., Yu, C., Brown, C., and Flynn, L. E. (2018). Decellularized adipose tissue scaffolds for soft tissue regeneration and adiposederived stem/stromal cell delivery. Methods Mol. Biol. 1773, 53-71. doi: 10. 1007/978-1-4939-7799-4_6

Moseti, D., Regassa, A., and Kim, W. K. (2016). Molecular regulation of adipogenesis and potential anti-adipogenic bioactive molecules. Int. J. Mol. Sci. 17:124. doi: 10.3390/ijms17010124

Mosser, D. M., and Edwards, J. P. (2008). Exploring the full spectrum of macrophage activation. Nat. Rev. Immunol. 8, 958-969. doi: 10.1038/nri2448

Murata, Y., Doi, T., Taniguchi, H., and Fujiyoshi, Y. (2005). Proteomic analysis revealed a novel synaptic proline-rich membrane protein (PRR7) associated with PSD-95 and NMDA receptor. Biochem. Biophys. Res. Commun. 327, 183-191. doi: 10.1016/j.bbrc.2004.11.154

Nakai, W., Yoshida, T., Diez, D., Miyatake, Y., Nishibu, T., Imawaka, N., et al. (2016). A novel affinity-based method for the isolation of highly purified extracellular vesicles. Sci. Rep. 6:33935.

Narayanan, K., Kumar, S., Padmanabhan, P., Gulyas, B., Wan, A. C. A., and Rajendran, V. M. (2018). Lineage-specific exosomes could override extracellular matrix mediated human mesenchymal stem cell differentiation. Biomaterials 182, 312-322. doi: 10.1016/j.biomaterials.2018.08.027

Narayanan, R., Huang, C. C., and Ravindran, S. (2016). Hijacking the cellular mail: exosome mediated differentiation of mesenchymal stem cells. Stem Cells Int. 2016:3808674.

Nic-Can, G. I., Rodas-Junco, B. A., Carrillo-Cocom, L. M., Zepeda-Pedreguera, A., Penaloza-Cuevas, R., Aguilar-Ayala, F. J., et al. (2019). Epigenetic regulation of adipogenic differentiation by histone lysine demethylation. Int. J. Mol. Sci. 20:3918. doi: $10.3390 /$ ijms20163918

Nie, J., Yi, Y., and Zhu, Y. (2020). [Construction of tissue engineered adipose by human adipose tissue derived extracellular vesicle combined with decellularized adipose tissues scaffold]. Zhongguo Xiu Fu Chong Jian Wai Ke Za Zhi 34, $226-233$.

Nolan, J. P., and Duggan, E. (2018). Analysis of individual extracellular vesicles by flow cytometry. Methods Mol. Biol. 1678, 79-92. doi: 10.1007/978-1-49397346-0_5

Oeyen, E., Van Mol, K., Baggerman, G., Willems, H., Boonen, K., Rolfo, C., et al. (2018). Ultrafiltration and size exclusion chromatography combined with asymmetrical-flow field-flow fractionation for the isolation and characterisation of extracellular vesicles from urine. J. Extracell. Vesicles 7:1490143. doi: 10.1080/ 20013078.2018.1490143

Pittenger, M. F., Mackay, A. M., Beck, S. C., Jaiswal, R. K., Douglas, R., Mosca, J. D., et al. (1999). Multilineage potential of adult human mesenchymal stem cells. Science 284, 143-147. doi: 10.1126/science.284.5411.143

Qian, S., Zhang, J. Y., Kay, M. A., and Jacobs-Lorena, M. (1987). Structural analysis of the Drosophila rpA1 gene, a member of the eucaryotic A type ribosomal protein family. Nucleic Acids Res. 15, 987-1003. doi: 10.1093/nar/15.3.987

Qiu, G., Zheng, G., Ge, M., Wang, J., Huang, R., Shu, Q., et al. (2019). Functional proteins of mesenchymal stem cell-derived extracellular vesicles. Stem Cell Res. Ther. 10:359.

Rabiee, A., Kruger, M., Ardenkjaer-Larsen, J., Kahn, C. R., and Emanuelli, B. (2018). Distinct signalling properties of insulin receptor substrate (IRS)-1 and IRS-2 in mediating insulin/IGF-1 action. Cell Signal. 47, 1-15. doi: 10.1016/j. cellsig.2018.03.003

Raposo, G., Nijman, H. W., Stoorvogel, W., Liejendekker, R., Harding, C. V., Melief, C. J., et al. (1996). B lymphocytes secrete antigen-presenting vesicles. J. Exp. Med. 183, 1161-1172. doi: 10.1084/jem.183.3.1161

Reilly, G. C., and Engler, A. J. (2010). Intrinsic extracellular matrix properties regulate stem cell differentiation. J. Biomech. 43, 55-62. doi: 10.1016/j. jbiomech.2009.09.009

Rittie, L. (2015). Another dimension to the importance of the extracellular matrix in fibrosis. J. Cell Commun. Signal. 9, 99-100. doi: 10.1007/s12079-015-0282-x

Rivoltini, L., Chiodoni, C., Squarcina, P., Tortoreto, M., Villa, A., Vergani, B., et al. (2016). TNF-related apoptosis-inducing ligand (TRAIL)-armed exosomes deliver proapoptotic signals to tumor site. Clin Cancer Res 22, 3499-3512. doi: 10.1158/1078-0432.ccr-15-2170

Salomon, C., Guanzon, D., Scholz-Romero, K., Longo, S., Correa, P., Illanes, S. E., et al. (2017). Placental exosomes as early biomarker of preeclampsia: potential role of exosomal MicroRNAs across gestation. J. Clin. Endocrinol. Metab. 102, 3182-3194. doi: 10.1210/jc.2017-00672

Samareh Salavati Pour, M., Vahidi, R., Lashkari, M., Derakhshani, A., Ameri, Z., and Farsinejad, A. (2020). Cord blood serum harvesting by hydroxyethyl starch: a fetal bovine serum alternative in expansion of umbilical cord-derived mesenchymal stem cells. Cytotechnology 72, 551-567. doi: 10.1007/s10616020-00404-9

Shenoda, B. B., and Ajit, S. K. (2016). Modulation of immune responses by exosomes derived from antigen-presenting cells. Clin. Med. Insights Pathol. 9, $1-8$.

Shi, C., Huang, F., Gu, X., Zhang, M., Wen, J., Wang, X., et al. (2016). Adipogenic miRNA and meta-signature miRNAs involved in human adipocyte differentiation and obesity. Oncotarget 7, 40830-40845. doi: 10.18632/ oncotarget. 8518

Shu, S., Yang, Y., Allen, C. L., Hurley, E., Tung, K. H., Minderman, H., et al. (2020). Purity and yield of melanoma exosomes are dependent on isolation method. J. Extracell. Vesicles 9:1692401. doi: 10.1080/20013078.2019.1692401

Skliar, M., and Chernyshev, V. S. (2019). Imaging of extracellular vesicles by atomic force microscopy. J. Vis. Exp. 151:59254.

Soares Martins, T., Catita, J., Martins Rosa, I., da Cruz e Silva, A. B., and Henriques, A. G. (2018). Exosome isolation from distinct biofluids using precipitation and column-based approaches. PLoS One 13:e0198820. doi: 10.1371/journal.pone. 0198820

Sokolova, V., Ludwig, A. K., Hornung, S., Rotan, O., Horn, P. A., Epple, M., et al. (2011). Characterisation of exosomes derived from human cells by nanoparticle tracking analysis and scanning electron microscopy. Colloids Surf. B Biointerfaces 87, 146-150. doi: 10.1016/j.colsurfb.2011.05.013

Suzuki, K., Akita, S., Yoshimoto, H., Ohtsuru, A., Hirano, A., and Yamashita, S. (2019). Biological features implies potential use of autologous adipose-derived stem/progenitor cells in wound repair and regenerations for the patients with lipodystrophy. Int. J. Mol. Sci. 20:5505. doi: 10.3390/ijms20215505

Svensson, K. J., Christianson, H. C., Wittrup, A., Bourseau-Guilmain, E., Lindqvist, E., Svensson, L. M., et al. (2013). Exosome uptake depends on ERK1/2-heat shock protein 27 signaling and lipid Raft-mediated endocytosis negatively regulated by caveolin-1. J. Biol. Chem. 288, 17713-17724. doi: 10.1074/jbc. m112.445403

Szatanek, R., Baj-Krzyworzeka, M., Zimoch, J., Lekka, M., Siedlar, M., and Baran, J. (2017). The methods of choice for extracellular vesicles (EVs) characterization. Int. J. Mol. Sci. 18:1153. doi: 10.3390/ijms18061153

Taverna, S., Flugy, A., Saieva, L., Kohn, E. C., Santoro, A., Meraviglia, S., et al. (2012). Role of exosomes released by chronic myelogenous leukemia cells in angiogenesis. Int. J. Cancer 130, 2033-2043. doi: 10.1002/ijc.26217

Tian, T., Zhu, Y. L., Zhou, Y. Y., Liang, G. F., Wang, Y. Y., Hu, F. H., et al. (2014). Exosome uptake through clathrin-mediated endocytosis and macropinocytosis and mediating miR-21 delivery. J. Biol. Chem. 289, 22258-22267. doi: 10.1074/ jbc.m114.588046

Tomasoni, S., Longaretti, L., Rota, C., Morigi, M., Conti, S., Gotti, E., et al. (2013). Transfer of growth factor receptor mRNA via exosomes unravels the regenerative effect of mesenchymal stem cells. Stem Cells Dev. 22, 772-780. doi: $10.1089 / \mathrm{scd} .2012 .0266$

Trams, E. G., Lauter, C. J., Salem, N. Jr., and Heine, U. (1981). Exfoliation of membrane ecto-enzymes in the form of micro-vesicles. Biochim. Biophys. Acta 645, 63-70. doi: 10.1016/0005-2736(81)90512-5

Van Nguyen, T. T., Vu, V. V., and Pham, P. V. (2020). Transcriptional factors of thermogenic adipocyte development and generation of brown and beige adipocytes from stem cells. Stem Cell Rev. Rep. 16, 876-892. doi: 10.1007/ s12015-020-10013-w

Walker, C., Mojares, E., and Del Rio Hernandez, A. (2018). Role of extracellular matrix in development and cancer progression. Int. J. Mol. Sci. 19:3028. doi: $10.3390 /$ ijms 19103028

Wan, Z., Chen, X., Gao, X., Dong, Y., Zhao, Y., Wei, M., et al. (2019). Chronic myeloid leukemia-derived exosomes attenuate adipogenesis of adipose derived mesenchymal stem cells via transporting miR-92a-3p. J. Cell Physiol. 234, 21274-21283. doi: $10.1002 /$ jcp. 28732 
Wang, C., Wang, M., Xu, T., Zhang, X., Lin, C., Gao, W., et al. (2019). Engineering bioactive self-healing antibacterial exosomes hydrogel for promoting chronic diabetic wound healing and complete skin regeneration. Theranostics 9, 65-76. doi: 10.7150/thno.29766

Wang, D., Xing, N., Yang, T., Liu, J., Zhao, H., He, J., et al. (2020). Exosomal lncRNA H19 promotes the progression of hepatocellular carcinoma treated with Propofol via miR-520a-3p/LIMK1 axis. Cancer Med. [Epub ahead of print].

Wang, F., Li, X., Li, Z., Wang, S., and Fan, J. (2020). Functions of circular RNAs in regulating adipogenesis of mesenchymal stem cells. Stem Cells Int. 2020:3763069.

Wang, H. S., Hung, S. C., Peng, S. T., Huang, C. C., Wei, H. M., Guo, Y. J., et al. (2004). Mesenchymal stem cells in the Whartons jelly of the human umbilical cord. Stem Cells 22, 1330-1337.

Wang, L., Johnson, J. A., Zhang, Q., and Beahm, E. K. (2013). Combining decellularized human adipose tissue extracellular matrix and adipose-derived stem cells for adipose tissue engineering. Acta Biomater. 9, 8921-8931. doi: 10.1016/j.actbio.2013.06.035

Wang, S., Li, X., Xu, M., Wang, J., and Zhao, R. C. (2017). Reduced adipogenesis after lung tumor exosomes priming in human mesenchymal stem cells via TGFbeta signaling pathway. Mol. Cell Biochem. 435, 59-66. doi: 10.1007/ s11010-017-3056-3

Wang, S., Li, X., Zhu, R., Han, Q., and Zhao, R. C. (2016). Lung cancer exosomes initiate global long non-coding RNA changes in mesenchymal stem cells. Int. J. Oncol. 48, 681-689. doi: 10.3892/ijo.2015.3272

Wang, X., Gao, L., Han, Y., Xing, M., Zhao, C., Peng, J., et al. (2018a). Silicon-enhanced adipogenesis and angiogenesis for vascularized adipose tissue engineering. Adv. Sci. 5:1800776. doi: 10.1002/advs.201800776

Wang, X., Omar, O., Vazirisani, F., Thomsen, P., and Ekstrom, K. (2018b). Mesenchymal stem cell-derived exosomes have altered microRNA profiles and induce osteogenic differentiation depending on the stage of differentiation. PLoS One 13:e0193059. doi: 10.1371/journal.pone.0193059

Wang, Y., Li, M., Wang, Y., Liu, J., Zhang, M., Fang, X., et al. (2019). A Zfp609 circular RNA regulates myoblast differentiation by sponging miR-194-5p. Int. J. Biol. Macromol. 121, 1308-1313. doi: 10.1016/j.ijbiomac.2018.09.039

Wang, Y., Zhang, Y., Cai, G., and Li, Q. (2020). Exosomes as actively targeted nanocarriers for cancer therapy. Int. J. Nanomedicine 15, 4257-4273. doi: 10.2147/ijn.s239548

Wei, Z., Batagov, A. O., Carter, D. R., and Krichevsky, A. M. (2016). Fetal bovine serum RNA interferes with the cell culture derived extracellular RNA. Sci. Rep. 6:31175.

Whiteside, T. L. (2018). Exosome and mesenchymal stem cell cross-talk in the tumor microenvironment. Semin. Immunol. 35, 69-79. doi: 10.1016/j.smim. 2017.12.003

Wu, Y., Deng, W., and Klinke, D. J. II (2015). Exosomes: improved methods to characterize their morphology, RNA content, and surface protein biomarkers. Analyst 140, 6631-6642. doi: 10.1039/c5an00688k

Xia, Y., He, X. T., Xu, X. Y., Tian, B. M., An, Y., and Chen, F. M. (2020). Exosomes derived from M0, M1 and M2 macrophages exert distinct influences on the proliferation and differentiation of mesenchymal stem cells. PeerJ 8:e8970. doi: 10.7717/peerj.8970

Xiao, Y., Li, Y., Yuan, Y., Liu, B., Pan, S., Liu, Q., et al. (2019). The potential of exosomes derived from colorectal cancer as a biomarker. Clin. Chim. Acta 490, 186-193. doi: 10.1016/j.cca.2018.09.007

Xing, X., Zhang, Z., Zhong, L., Ju, G., Zou, X., Zhu, Y., et al. (2016). Differentiation of human umbilical cord mesenchymal stem cells into steroidogenic cells in vitro. Exp. Ther. Med. 12, 3527-3534. doi: 10.3892/etm.2016. 3815

Xu, F., Xiang, Q., Huang, J., Chen, Q., Yu, N., Long, X., et al. (2019). Exosomal miR423-5p mediates the proangiogenic activity of human adipose-derived stem cells by targeting Sufu. Stem Cell Res. Ther. 10:106.

Xu, M., Yang, Q., Sun, X., and Wang, Y. (2020). Recent advancements in the loading and modification of therapeutic exosomes. Front. Bioeng. Biotechnol. 8:586130. doi: 10.3389/fbioe.2020.586130

Xue, C., Shen, Y., Li, X., Li, B., Zhao, S., Gu, J., et al. (2018). Exosomes derived from hypoxia-treated human adipose mesenchymal stem cells enhance angiogenesis through the PKA signaling pathway. Stem Cells Dev. 27, 456-465. doi: 10.1089/ scd.2017.0296
Xue, R., Wan, Y., Zhang, S., Zhang, Q., Ye, H., and Li, Y. (2014). Role of bone morphogenetic protein 4 in the differentiation of brown fat-like adipocytes. Am. J. Physiol. Endocrinol. Metab. 306, E363-E372.

Yao, Z., Qiao, Y., Li, X., Chen, J., Ding, J., Bai, L., et al. (2018). Exosomes exploit the virus entry machinery and pathway to transmit alpha interferon-induced antiviral activity. J. Virol. 92:e01578-18.

Yeo, R. W., Lai, R. C., Zhang, B., Tan, S. S., Yin, Y., Teh, B. J., et al. (2013). Mesenchymal stem cell: an efficient mass producer of exosomes for drug delivery. Adv. Drug Deliv. Rev. 65, 336-341. doi: 10.1016/j.addr.2012.07.001

Yin, H., Pasut, A., Soleimani, V. D., Bentzinger, C. F., Antoun, G., Thorn, S., et al. (2013). MicroRNA-133 controls brown adipose determination in skeletal muscle satellite cells by targeting Prdm16. Cell Metab. 17, 210-224. doi: 10. 1016/j.cmet.2013.01.004

Yuana, Y., Oosterkamp, T. H., Bahatyrova, S., Ashcroft, B., Garcia Rodriguez, P., Bertina, R. M., et al. (2010). Atomic force microscopy: a novel approach to the detection of nanosized blood microparticles. J. Thromb. Haemost. 8, 315-323. doi: 10.1111/j.1538-7836.2009.03654.x

Zarovni, N., Corrado, A., Guazzi, P., Zocco, D., Lari, E., Radano, G., et al. (2015). Integrated isolation and quantitative analysis of exosome shuttled proteins and nucleic acids using immunocapture approaches. Methods 87, 46-58. doi: 10. 1016/j.ymeth.2015.05.028

Zeng, Z., Li, Y., Pan, Y., Lan, X., Song, F., Sun, J., et al. (2018). Cancer-derived exosomal miR-25-3p promotes pre-metastatic niche formation by inducing vascular permeability and angiogenesis. Nat. Commun. 9:5395.

Zhang, H., Noohr, J., Jensen, C. H., Petersen, R. K., Bachmann, E., Teisner, B., et al. (2003). Insulin-like growth factor-1/insulin bypasses Pref-1/FA1-mediated inhibition of adipocyte differentiation. J. Biol. Chem. 278, 20906-20914. doi: 10.1074/jbc.m300022200

Zhang, H., Zhu, L., Bai, M., Liu, Y., Zhan, Y., Deng, T., et al. (2019). Exosomal circRNA derived from gastric tumor promotes white adipose browning by targeting the miR-133/PRDM16 pathway. Int. J. Cancer 144, 2501-2515. doi: 10.1002/ijc.31977

Zhang, J., Yi, Y., Yang, S., Zhu, Y., and Hu, X. (2018). [Effects of adiposederived stem cell released exosomes on proliferation, migration, and tube-like differentiation of human umbilical vein endothelial cells]. Zhongguo Xiu Fu Chong Jian Wai Ke Za Zhi 32, 1351-1357.

Zhang, J. W., Tang, Q. Q., Vinson, C., and Lane, M. D. (2004). Dominantnegative C/EBP disrupts mitotic clonal expansion and differentiation of 3T3-L1 preadipocytes. Proc. Natl. Acad. Sci. U.S.A. 101, 43-47. doi: 10.1073/pnas. 0307229101

Zhang, S., Chuah, S. J., Lai, R. C., Hui, J. H. P., Lim, S. K., and Toh, W. S. (2018). MSC exosomes mediate cartilage repair by enhancing proliferation, attenuating apoptosis and modulating immune reactivity. Biomaterials 156, 16-27. doi: 10.1016/j.biomaterials.2017.11.028

Zhang, S., Teo, K. Y. W., Chuah, S. J., Lai, R. C., Lim, S. K., and Toh, W. S. (2019). MSC exosomes alleviate temporomandibular joint osteoarthritis by attenuating inflammation and restoring matrix homeostasis. Biomaterials 200, 35-47. doi: 10.1016/j.biomaterials.2019.02.006

Zhang, W., Bai, X., Zhao, B., Li, Y., Zhang, Y., Li, Z., et al. (2018). Cell-free therapy based on adipose tissue stem cell-derived exosomes promotes wound healing via the PI3K/Akt signaling pathway. Exp. Cell Res. 370, 333-342. doi: 10.1016/j.yexcr.2018.06.035

Zhang, Y., Shi, S., Xu, Q., Zhang, Q., Shanti, R. M., and Le, A. D. (2019). SIS-ECM laden with GMSC-derived exosomes promote taste bud regeneration. J. Dent. Res. 98, 225-233. doi: 10.1177/0022034518804531

Zhang, Y., Yu, M., Dai, M., Chen, C., Tang, Q., Jing, W., et al. (2017). miR$450 \mathrm{a}-5 \mathrm{p}$ within rat adipose tissue exosome-like vesicles promotes adipogenic differentiation by targeting WISP2. J. Cell Sci. 130, 1158-1168.

Zhao, B., Wu, G. F., Zhang, Y. J., Zhang, W., Yang, F. F., Xiao, D., et al. (2017). [Effects of human amniotic epithelial stem cells-derived exosomes on healing of wound with full-thickness skin defect in rats]. Zhonghua Shao Shang Za Zhi $33,18-23$.

Zhao, H., Shang, Q., Pan, Z., Bai, Y., Li, Z., Zhang, H., et al. (2018). Exosomes from adipose-derived stem cells attenuate adipose inflammation and obesity through polarizing M2 macrophages and beiging in white adipose tissue. Diabetes 67, 235-247. doi: 10.2337/db17-0356

Zhao, J., Li, X., Hu, J., Chen, F., Qiao, S., Sun, X., et al. (2019). Mesenchymal stromal cell-derived exosomes attenuate myocardial ischaemia-reperfusion 
injury through miR-182-regulated macrophage polarization. Cardiovasc. Res. 115, 1205-1216. doi: 10.1093/cvr/cvz040

Zhou, Q., Xie, F., Zhou, B., Li, C., Kang, Y., Wu, B., et al. (2020). Fetal bovine serum-derived exosomes regulate the adipogenic differentiation of human bone marrow mesenchymal stromal cells in a cross-species manner. Differentiation 115, 11-21. doi: 10.1016/j.diff.2020.06.004

Zhu, D., Shi, S., Wang, H., and Liao, K. (2009). Growth arrest induces primarycilium formation and sensitizes IGF-1-receptor signaling during differentiation induction of 3T3-L1 preadipocytes. J. Cell Sci. 122, 2760-2768.

Zhu, L. P., Tian, T., Wang, J. Y., He, J. N., Chen, T., Pan, M., et al. (2018). Hypoxia-elicited mesenchymal stem cell-derived exosomes facilitates cardiac repair through miR-125b-mediated prevention of cell death in myocardial infarction. Theranostics 8, 6163-6177. doi: 10.7150/thno.28021

Zhu, M., Liu, X., Li, W., and Wang, L. (2020). Exosomes derived from mmu_circ_0000623-modified ADSCs prevent liver fibrosis via activating autophagy. Hum. Exp. Toxicol. 39, 1619-1627. doi: 10.1177/0960327120931152

Zhu, W., Guo, M., Yang, W., Tang, M., Chen, T., Gan, D., et al. (2020). CD41deficient exosomes from non-traumatic femoral head necrosis tissues impair osteogenic differentiation and migration of mesenchymal stem cells. Cell Death Dis. 11:293.

Zuo, R., Liu, M., Wang, Y., Li, J., Wang, W., Wu, J., et al. (2019). BM-MSC-derived exosomes alleviate radiation-induced bone loss by restoring the function of recipient BM-MSCs and activating Wnt/beta-catenin signaling. Stem Cell Res. Ther. 10:30.

Conflict of Interest: The authors declare that the research was conducted in the absence of any commercial or financial relationships that could be construed as a potential conflict of interest.

Copyright (c) 2021 Zhong, Li, Wang, Wang, Wang, Tian, Bai, Miao and Fan. This is an open-access article distributed under the terms of the Creative Commons Attribution License (CC BY). The use, distribution or reproduction in other forums is permitted, provided the original author(s) and the copyright owner(s) are credited and that the original publication in this journal is cited, in accordance with accepted academic practice. No use, distribution or reproduction is permitted which does not comply with these terms. 